University of Nebraska - Lincoln

DigitalCommons@University of Nebraska - Lincoln target in the United States

\author{
Brian G. Rector \\ USDA-ARS \\ Vili Harizanova \\ Agriculture University \\ René Sforza \\ USDA-ARS \\ Tim Widmer \\ USDA-ARS, tim.widmer@ars.usda.gov \\ Robert N. Wiedenmann \\ University of Arkansas
}

Follow this and additional works at: https://digitalcommons.unl.edu/usdaarsfacpub

Part of the Agricultural Science Commons

Rector, Brian G.; Harizanova, Vili; Sforza, René; Widmer, Tim; and Wiedenmann, Robert N., "Prospects for biological control of teasels, Dipsacus spp., a new target in the United States" (2006). Publications from USDA-ARS / UNL Faculty. 373.

https://digitalcommons.unl.edu/usdaarsfacpub/373

This Article is brought to you for free and open access by the U.S. Department of Agriculture: Agricultural Research Service, Lincoln, Nebraska at DigitalCommons@University of Nebraska - Lincoln. It has been accepted for inclusion in Publications from USDA-ARS / UNL Faculty by an authorized administrator of DigitalCommons@University of Nebraska - Lincoln. 


\title{
Prospects for biological control of teasels, Dipsacus spp., a new target in the United States
}

\author{
Brian G. Rector ${ }^{\mathrm{a}, *}$, Vili Harizanova ${ }^{\mathrm{b}}$, René Sforza ${ }^{\mathrm{a}}$, Tim Widmer ${ }^{\mathrm{a}}$, Robert N. Wiedenmann ${ }^{\mathrm{c}}$ \\ ${ }^{a}$ USDA-ARS, European Biological Control Laboratory, Montpellier, France \\ ${ }^{\mathrm{b}}$ Department of Entomology, Agriculture University, 12 Mendeleev Str., 4000 Plovdiv, Bulgaria \\ ${ }^{\mathrm{c}}$ Department of Entomology, University of Arkansas, Fayetteville, AR 72701, USA \\ Received 1 January 2005; accepted 16 September 2005 \\ Available online 7 November 2005
}

\begin{abstract}
Two closely related teasels (Dipsacales: Dipsacaceae, Dipsacus spp.) of European origin have become invasive weeds in the United States. Common teasel (Dipsacus fullonum L.) and cutleaf teasel (Dipsacus laciniatus L.) have likely been in North America for more than two centuries, having been introduced along with cultivated teasel [D. sativus (L.) Honckney], an obsolete crop plant. There are few records of American insects or pathogens attacking Dipsacus spp. Invasive teasels have recently begun to spread rapidly throughout much of their current range, for reasons that are not yet known. Common and/or cut-leaf teasel have been listed as noxious in five US states and as invasive in 12 other states and four national parks. Because the family Dipsacaceae is an exclusively Old World family, classical biological control is an important component of the overall management strategy of this weed in the US. Field surveys for natural enemies of $D$. fullonum and $D$. laciniatus in their native ranges and literature reviews of natural enemies of plants in the family Dipsacaceae have yielded 102 species of insects in six orders, as well as 27 fungi from 10 orders, three mites, one nematode, and two viruses. Due to the biennial nature of these weeds, a strategy to assign highest priority to biological control candidates attacking first-year (rosette) plants has been established. Candidates selected for further study based on this strategy include Chromatomyia ramosa (Hendel) (Diptera: Agromyzidae), Longitarsus strigicollis Wollaston (Coleoptera: Chrysomelidae), Epitrimerus knautiae Liro (Acarina: Eriophyiidae), Euphydryas desfontainii (Godart) (Lepidoptera: Nymphalidae), Erysiphe knautiae Duby (Erysiphales: Erysiphaceae), and Sphaerotheca dipsacearum (Tul. and C. Tul.) (Erysiphales: Erysiphaceae).
\end{abstract}

(C) 2005 Elsevier Inc. All rights reserved.

Keywords: Classical biological control; Invasive species; Dipsacus fullonum; Common teasel; Dipsacus laciniatus; Cutleaf teasel; Dipsacus sativus; Cultivated teasel; Chromatomyia ramosa; Longitarsus strigicollis, Epitrimerus knautiae; Erysiphe knautiae; Euphydryas desfontainii; Sphaerotheca dipsacearum

\section{Introduction}

Teasels (Dipsacus spp.; Dipsacales: Dipsacacae) are increasing their status as invasive alien weeds in non-agricultural habitats in the US (Sforza, 2004). Invasive teasels occur in 43 US states, being absent only from the extreme southeastern states, North Dakota, Alaska, and Hawai'i (Singhurst and Holmes, 2001; USDA, 2004; Rector, unpublished data). Teasels also occur in the Canadian provinces

\footnotetext{
${ }^{*}$ Corresponding author. Fax: +33 499623049 .

E-mail address: brector@ars-ebcl.org (B.G. Rector).
}

of Ontario, Quebec, British Columbia (Werner, 1975a), and Manitoba (Environment Canada, 2003). Four states in the western and midwestern US (CO, IA, MO, and NM) have declared Dipsacus fullonum L. (common teasel) noxious, and Dipsacus laciniatus L. (cutleaf teasel) is considered noxious in Colorado and Oregon. Cultivated teasel, Dipsacus sativus (L.) Honckney, is also present in the US. Teasels are listed as invasive by 12 other states and are listed as affecting natural areas in four national parks (USDI-NPS, 2003). This combined status led to the initiation of a governmentsponsored biological control program against these species.

The Dipsacaceae sensu lato is an exclusively Old World family, except in cases where species have been moved by 
humans. Thus, no members of the Dipsacaceae are native to the New World (Sforza, 2004). In addition, there are no plants of significant economic importance within the family Dipsacaceae (Bailey, 1951). The center of origin of the subgenus Dipsacus L., which includes all invasive Dipsacus spp. in N. America, appears to be in southern Europe, due to the greatest diversity and greatest number of endemic species in that region (Fig. 2A) (Verlaque, 1985). A molecular genetic study is underway to investigate the centers of origin of $D$. fullonum and D. laciniatus and the geographical origins of genotypes of these species that are invasive in the US.

This paper documents the known herbivores and pathogens of plants in the family Dipsacaceae in general, and those of $D$. fullonum and D. laciniatus in particular. The findings of initial field surveys in the native ranges of $D$. fullonum and D. laciniatus are presented, as well as a summary of the existing literature and database resources. Using this information, we make a case for the prioritization of those herbivores and pathogens that have sufficient potential as biological control candidates to warrant intensive impact and host-specificity testing.

\section{Teasels in the United States}

\subsection{Synonomy and history of the target in the US}

There has been some confusion over the synonomy of teasel species. Common teasel (sometimes referred to colloquially as "Indian teasel") has frequently been called $D$. sylvestris (Huds.) rather than D. fullonum, particularly in the North American literature (e.g., Glass, 1991; Huenneke and Thomson, 1995; Judd, 1983). In addition, those who refer to common teasel as $D$. sylvestris have sometimes used $D$. fullonum as the name for cultivated (or "Fuller's") teasel, which is otherwise known as D. sativus. A detailed discussion of this taxonomic issue by Ferguson and Brizicky (1965) concluded that the most appropriate name for common teasel is $D$. fullonum. In addition, because $D$. fullonum is the type species of the genus, the species name cannot be changed (Bobrov, 1957). The Weed Science Society of America refers to common teasel as D. fullonum, cutleaf teasel as $D$. laciniatus, and cultivated teasel as $D$. sativus (WSSA, 2005), and we will use this nomenclature for the remainder of the paper.

Cultivated teasel heads were grown in the pre-industrial era for use in carding or "teasing" wool fibers (Ryder, 1998). The intentional cultivation of teasel has been documented to as far back as 12th century France (AndrieuPonel et al., 2000) and may date to the Roman Empire (Ryder, 1998). Cultivated teasel (D. sativus) was still an important crop in Europe during the height of European colonization of other continents. This was likely the species of "fuller's teasel" that was introduced by John Bartram into Pennsylvania in 1728 (Tabor, 2003).

Dipsacus sativus very closely resembles $D$. fullonum and has long been considered to be domesticated from that species (Darwin, 1859). D. laciniatus is also similar in appear- ance to $D$. sativus, particularly the seeds and seedheads. Introduction and spread of D. fullonum and D. laciniatus in $\mathrm{N}$. America (as well as other former European colonies) almost certainly arose, at least in part, from contamination of $D$. sativus seed, although the introductions themselves do not appear to have been recorded in the literature.

Despite its utility in the processing of wool, teasel was never a major crop. Relatively little acreage was needed to fulfill the demands of the industry. For example, in 1920 the entire British demand of 10,000,000 teasels could be produced on less than 400 ha of land (Ryder, 1998). As a result, there is little scientific literature concerning teasel production or its associated pests.

Stoner (1951) described an aphid-transmitted virus disease from a "commercial planting of fuller's teasel ... south of Sunnyvale, Calif.," in May, 1948. Thus, D. sativus was still under cultivation in the US in the mid-20th century. Topham (1968) also states that teasels were being cultivated in the states of Oregon and New York in that period. Based on the above dates and locations, $D$. fullonum and D. laciniatus have had many opportunities for introduction into and spread across America over the course of two centuries.

Spread of invasive teasels through commerce and general interest in the plant continues. Gardeners plant teasel for its striking appearance and purple flowers, its use in dried flower arrangements, and its attractiveness to butterflies, bumblebees, and natural enemies of crop pests (Judd, 1983). Teasel seed, as well as dried teasel flower arrangements (including seed heads that may to contain viable seed), can be purchased through the internet. Also on the internet, one can find numerous teasel-related homeopathic medicinal items and testimonials to their purported efficacy (e.g., Hall and Wood, 2001; Nature's Health Co, 2001; Teeguarden, 2004). Consumers wishing to utilize the plant for any of these purposes may be contributing to the spread of teasel by growing the plants in their gardens or inadvertently spreading viable seed. Teasel seed has also been used in birdseed mixes and may have spread through commercial birdseed sales.

\subsection{Target life history and factors affecting weediness}

Common, cultivated and cutleaf teasels are often considered biennials because sufficient energy for reproduction is not gained in the first full year of growth, with bolting and flowering normally occurring in the second year. However, under adverse biotic or abiotic conditions (including herbivory or other natural enemy attack) the plant may need additional years to bolt, becoming less likely to do so with each passing year (Werner, 1975b). Given that reproduction only occurs once, no matter the length of the preceding vegetative period, these three Dipsacus species are properly referred to as monocarpic, short-lived perennials.

Seeds of common teasel germinate from spring to late summer (Werner, 1975a), after which rosette leaves and a taproot form. The plant grows vegetatively as a rosette, storing energy in the taproot until there is sufficient storage 
to sustain bolting, flowering, and seed production; bolting has been linked to rosettes exceeding a minimum diameter of $30 \mathrm{~cm}$ (Werner, 1975b). Plants that achieve this size late in the year bolt the following spring. At the terminus of each stem a single ovoid to cylindrical seedhead forms. The seedhead on the central stem is the largest on the plant and it flowers first, usually in midsummer. Seedheads on secondary stems flower after the central head, over the course of up to 40 days (Chuko and Hanyu, 1990).

Although self-pollination appears possible, allogamous fertilization, following cross-pollination facilitated by bumblebees, macrolepidoptera, and other insects, is the most common method of reproduction for D. fullonum (Werner, 1975a) and D. laciniatus (Verlaque, 1985). Seeds mature within the head in autumn and most fall from the head before the onset of winter, although some viable seed remain in the head into the following spring (B. Rector, unpublished data). In studies on $D$. fullonum, Werner (1975c) reported that virtually all of the seeds from a given plant $(99.9 \%)$ fall within $1.5 \mathrm{~m}$ of the plant. Long range seed dispersal occurs mainly due to floating seeds in floodwaters or in other flowing waters (e.g., ditches or streams). Common teasel seeds can float up to 22 days without significant reduction in viability (Werner, 1975a). In years without flooding, dense teasel populations can build up as entire seed loads are successively dumped in one area.

Individual teasel plants compete for resources with neighboring plants by spreading large rosette leaves that shade the ground. Common teasel's taproot can extend deeper than the roots of many of its annual and biennial competitors in North America (Werner, 1975a). A teasel plant can produce up to 40 seedheads, the largest of which can produce up to 2000 seeds. Common teasel has been shown to tolerate elevated salinity levels in comparison to other roadside plant species, thus conferring a competitive advantage to teasel in areas where roads are salted in the winter months (Beaton and Dudley, 2004).

Common teasel occurs in dry-mesic and mesic savannas, wetlands, lake borders, agricultural fields, pastureland, successional fields, and developed land (Iverson et al., 1999). The plant grows best in full sun and in poorly drained soils, especially in areas prone to flooding. It is often found in moderately disturbed habitats, such as along roadsides or in waste areas, where seed germination has been shown to be enhanced (Roberts, 1986). Teasel can colonize prairie and savanna habitats, sometimes resulting in monocultures and the exclusion of native species (Glass, 1991; Huenneke and Thomson, 1995). No one has attempted to calculate an economic value for the impact of these invasions.

\section{Management options}

Current management options for invasive teasels include herbicide treatment of rosettes, mowing of bolted and flowering stems, or, in environmentally sensitive settings, recruiting volunteers to dig up the deep taproots of rosettes and cut and remove stems of bolted plants (Glass, 1991).
Fire is inappropriate where teasel populations occur along roads with heavy vehicular traffic and also inappropriate in many natural settings where the risk of wildfire is important. In addition, the plant's most common habitats are characterized by moist soils, which could obviate the use of fire as a general control practice. Effectiveness of other control methods varies considerably (Cheesman, 1998). Mowing of early season stems is considered ineffective since plants can often bolt a second time, necessitating a second mowing. Mowing flowering plants is only effective if the heads are collected and removed - otherwise the mower can scatter seedheads containing viable seed, even when heads are cut before seed reach full maturity (Cheesman, 1998; Solecki, 1989). Glyphosate and 2-4 D have proven effective in killing teasel, but applications over several years are required to manage an established population (Skolnik, 1999), and their use may be restricted in environmentally sensitive areas, such as near waterways.

Given the difficulties controlling established teasel populations, alternative approaches to control are warranted. Biological control of teasel represents one available option. Because of the species-specific nature of biological control, where candidate agents are chosen after extensive hostspecificity testing, it can be an effective option while minimizing effects on non-target species (Quimby et al., 2003). Biological control is a particularly attractive option for teasels in North America because of the close phylogenetic relationship between the two invasive teasel species, $D$. fullonum and D. laciniatus, as well as the absence of any economically important or native American members of the family Dipsacaceae.

\section{Identification of herbivores and pathogens associated with teasels}

Field surveys for herbivores and pathogens that attack Dipsacus spp. have been conducted so far in Bulgaria, France, Greece, Hungary, Italy, Romania, Russia, Slovenia, Spain, Turkey, and Ukraine, from 2001-2004 (Fig. 1). In general, field surveys were conducted by traveling within the known ranges of $D$. fullonum and D. laciniatus (see Fig. 2A) and stopping to inspect plants for herbivore or pathogen damage whenever these species were encountered. A priori information regarding known locations of either of these species or their natural enemies was used whenever it was available. These surveys (Table 1), as well as literature searches (Table 2), have yielded a large number of natural enemies to screen for their suitability as biological control agents of invasive teasels. To date, the total pool of biological control candidates (BCCs) identified from the combined field and literature surveys includes 102 species of insects in six orders, as well as 27 fungi from 10 orders, three mites, one nematode, and two viruses (see Tables 1 and 2). Much of the natural range of $D$. fullonum and $D$. laciniatus, as well as the congeners of these species, remains to be surveyed, including much of northern Europe and Scandinavia, the British Isles, the remainder of eastern 


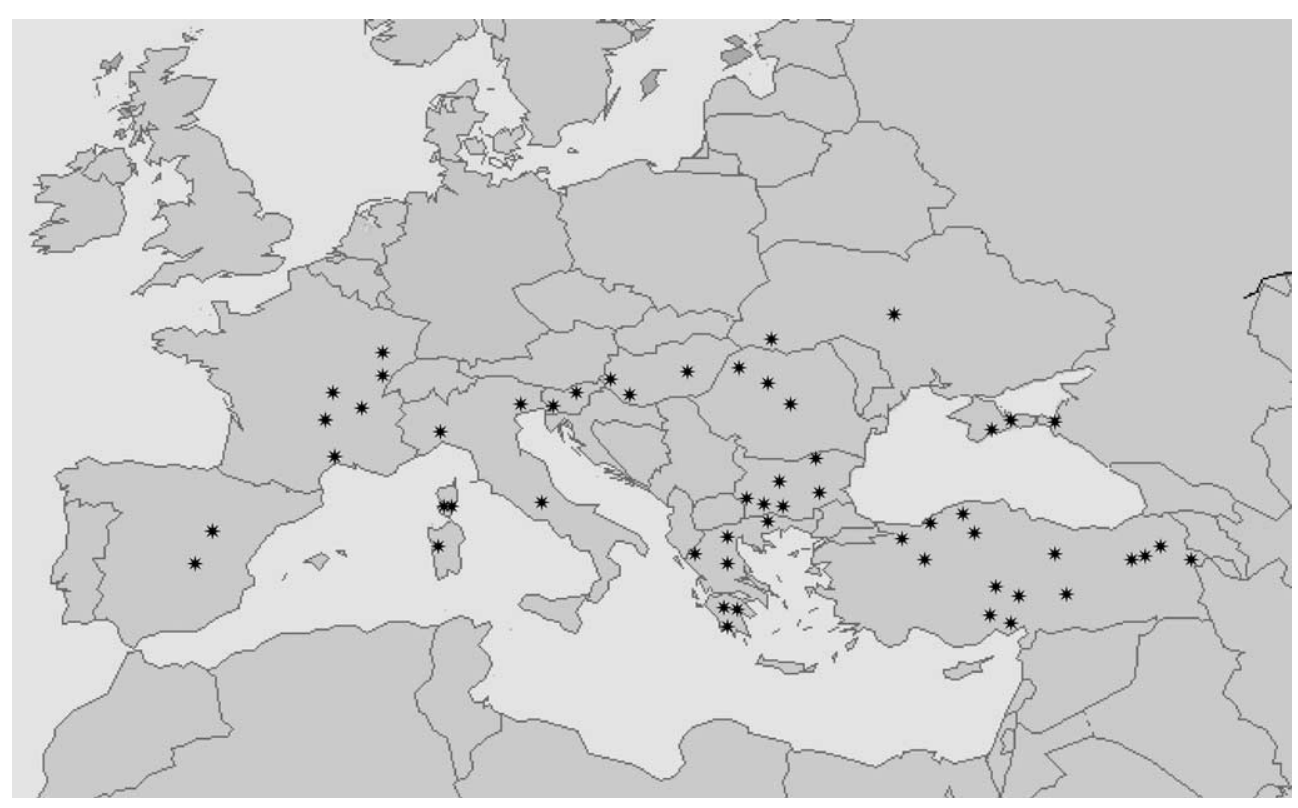

Fig. 1. Survey sites for herbivores and pathogens of Dipsacus spp.

Europe and European Russia, mediterranean northwest Africa, western Turkey and parts of southwest Asia (Fig. 2) (Verlaque, 1985).

In the literature survey, the pool of BCCs was expanded to the broadest logical sense, including those herbivores or pathogens that have been described attacking any plants in the entire family Dipsacaceae (Table 2). An attempt was made to find any reference to Dipsacus using all literature searching abstract journals and databases, in the biological, zoological, and agricultural sciences, particular those references pertaining to natural enemies of Dipsacus spp. or any other plant in the Dipsacaceae. Natural enemies found to feed exclusively within this family would not be expected to attack any North American natives or any economically important species. Indeed, a BCC whose primary host is in the Dipsacaceae but is not a Dipsacus sp., could become a promising candidate (Hokkanen and Pimentel, 1984), although the first step in testing any such candidate would be to establish that it will feed on the target. Apart from those herbivores that feed on Dipsacaceae, a list of some pollen and nectar feeding insects and other pollinators associated with $D$. fullonum in eastern N. America is also available (Judd, 1983).

\subsection{Prioritzing biological control candidates}

In prioritizing intensive research on selected $\mathrm{BCCs}$, a key criterion that must be met is the specificity of the BCC for the target plant. Information on each species's host range in Tables 1 and 2 was sought in the literature and in online databases. An index of specificity was generated using this information to express host ranges relative to the genus Dipsacus L. and the family Dipsacaceae (see Tables 1 and 2). Of the 135 BCCs in Tables 1 and 2, 100 are known to attack plants outside the Dipsacaceae. These species, especially those that are highly polyphagous or known to attack economically important plants, immediately assume a very low priority relative to the other BCCs limited to hosts in the Dipsacaceae. Thirty-two of the BCCs listed in Tables 1 and 2 are only known from hosts in the Dipsacaceae while three have host ranges that are not yet known. Of the 32 BCCs only known from Dipsacaceous hosts, 18 are known to attack Dipsacus spp.; and of these 18, five are known only from Dipsacus hosts (Tables 1 and 2).

Based on the biennial development of $D$. fullonum and $D$. laciniatus, the requirement of a minimum rosette diameter for successful bolting in D. fullonum (Werner, 1975b), and the diminishing probability of bolting with age (Werner, 1975b), BCCs that attack the taproot or the rosette hold the greatest promise for biological control of teasels. Damage by such agents should either directly or indirectly (in the cases of root- or rosette-feeders, respectively) reduce the storage reserves necessary for bolting and could result in stunted flowering plants with reduced numbers of seedheads or even death without flowering. In addition, damage to the root can open the plant to infection by soil-borne pathogens that would not normally infest a healthy root. Bolting plants and seeds would be important secondary targets. Among the 32 BCCs that are currently only known from hosts in the Dipsacaceae (see Tables 1 and 2), six are known to attack either the roots or rosettes. For many foliage-attacking species, information is not available that indicates whether these specialize on the rosette stage. Five of the 32 BCCs specific to the Dipsacaceae are described from either flowers or seeds.

Other criteria commonly used for prioritizing intensive study of BCCs include but are not limited to severity of damage to the target, coincidence of target and BCC phenologies, and BCC fecundity and distribution (Blossey, 1995; Harris, 1973, 1991; Wapshere, 1974). However, the importance of particular criteria can vary depending on the target, the similarity or difference between native and 
A

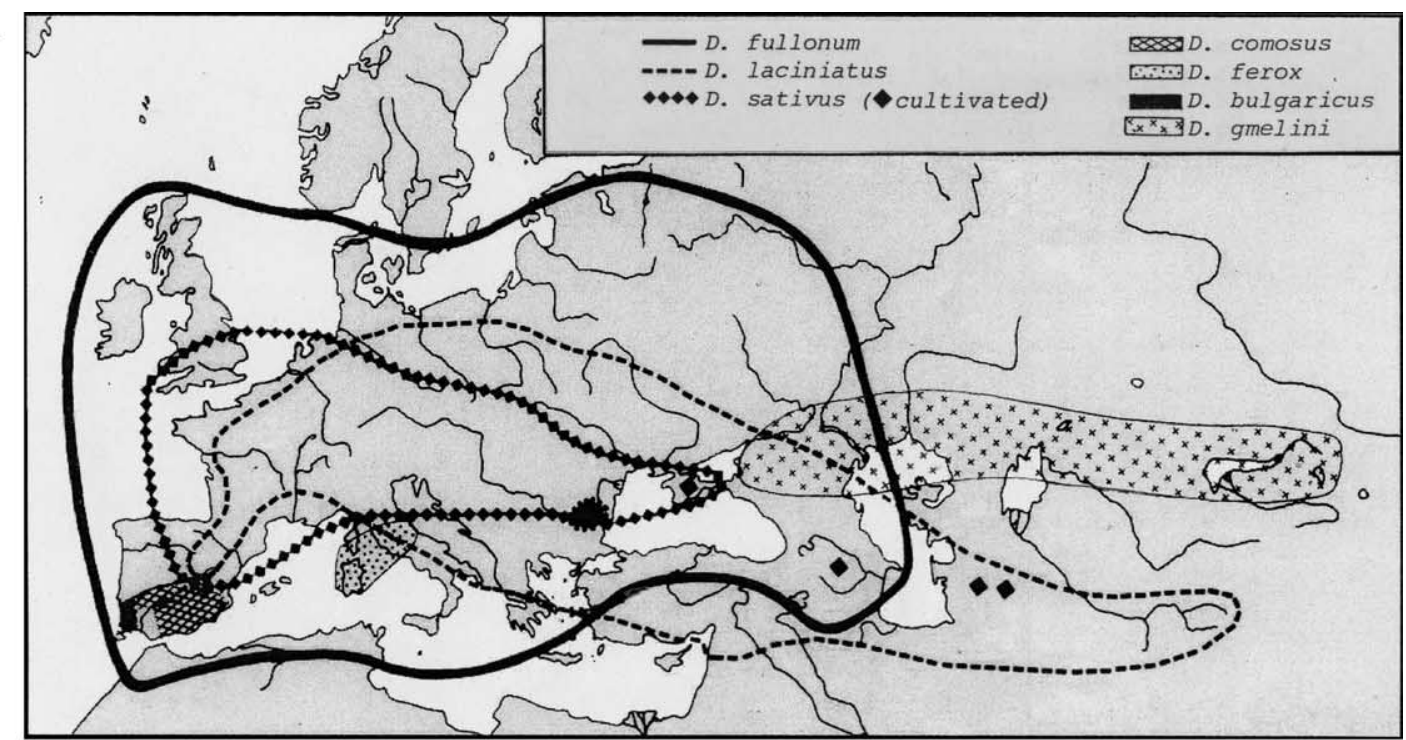

B

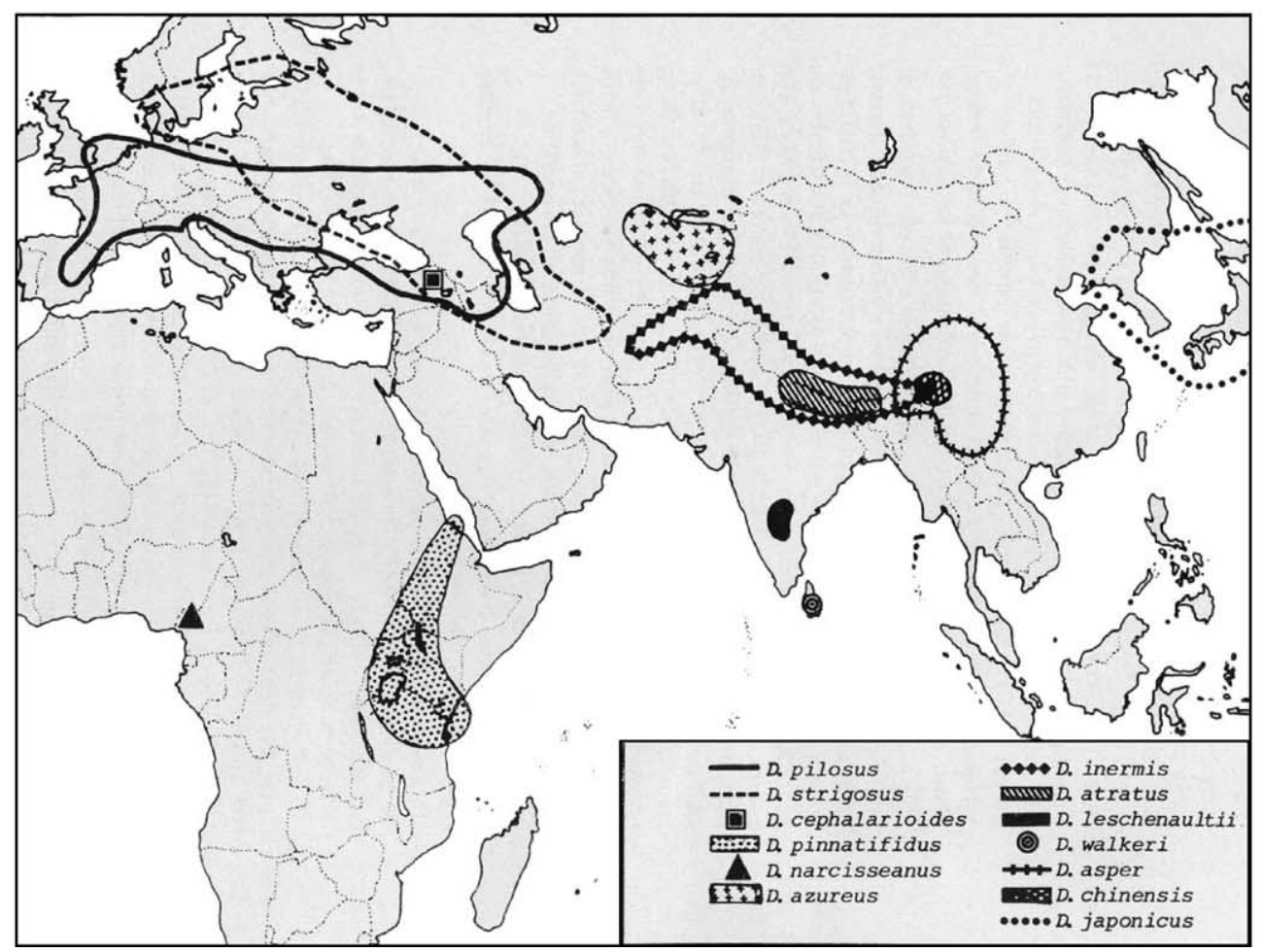

Fig. 2. Native range of the genus Dipsacus L. including the subgroups Dipsacus (A) and Sphaerodipsacus (B) (Verlaque, 1985).

invaded environments, or extreme strengths or weaknesses among members of a given pool of BCCs for one or more of the criteria. From among those candidates listed in Tables 1 and 2, the following BCCs have been assigned the highest priority for going forward into host-specificity and impact testing, based on the above guidelines.

\subsection{Candidates already in the US}

Thus far, literature and field surveys have yielded evidence of only one native North American, herbivore on teasels. However, this evidence is somewhat anecdotal and has yet to be confirmed by the authors in the field. According to Covell (1984) larvae of the noctuid moth Papaipema arctivorens Hampton feed in rhizomes of thistle, teasel, and burdock in eastern N. America, although the effect that this feeding might have on the teasel plant or on invasive teasel populations is not discussed. Since a native American BCC would have the potential of avoiding many of the quarantine-related permits and testing that foreign BCCs require, the authors will attempt to locate wild populations of $P$. arctivorens in N. America to confirm this insect's host-range as reported by Covell (1984). Preparation of such a BCC for distribution would 
Table 1

Identified invertebrate herbivores and pathogens collected by the authors from Dipsacus spp. in Europe and Asia Minor in the years 2001-2004

\begin{tabular}{|c|c|c|c|c|c|c|c|}
\hline Order & Family & Genus & Species (author) & Damage & Specificity $^{\mathrm{a}}$ & Range $^{c}$ & Reference(s) \\
\hline \multicolumn{8}{|l|}{ Fungi } \\
\hline Helotiales & Sclerotiniaceae & Sclerotinia & $\begin{array}{l}\text { sclerotiorum (Lib.) } \\
\text { de Bary }\end{array}$ & $\begin{array}{l}\text { Seedling, } \\
\text { bolted plant }\end{array}$ & $\mathrm{X}$ & Co & $\begin{array}{l}\text { Brosten and Sands (1986); } \\
\text { Cother et al. (1996) }\end{array}$ \\
\hline Moniliales & Moniliaceae & Alternaria & $\begin{array}{l}\text { alternata }(\mathrm{Fr} .) \\
\text { Keissl. }\end{array}$ & Seedling/rosette & $\mathrm{X}$ & $\mathrm{Co}$ & Widmer, unpublished data \\
\hline Sphaeropsidales & Sphaeropsidaceae & Phoma & exigua Sacc. & Crown and roots & $\mathrm{X}$ & Co & Widmer, unpublished data \\
\hline \multicolumn{8}{|l|}{ Mites } \\
\hline Acarina & Tetranychidae & Tetranychus & urticae Koch & Foliage, stems & $\mathrm{X}$ & $\mathrm{Co}$ & $\begin{array}{l}\text { Rector and Sforza, } \\
\text { unpublished data }\end{array}$ \\
\hline \multicolumn{8}{|l|}{ Insects } \\
\hline \multirow[t]{18}{*}{ Coleoptera } & Cerambycidae & Agapanthia & osmanlis Reiche & $\begin{array}{l}\text { Stalk, bolting } \\
\text { plants }\end{array}$ & G & $\mathrm{Eu}$ & $\begin{array}{l}\text { Kovacs (1998); M. Rejzek, } \\
\text { pers. comm. }\end{array}$ \\
\hline & \multirow[t]{17}{*}{ Chrysomelidae } & Altica & oleracea (L.) & foliage & $\mathrm{X}$ & $\mathrm{Pa}$ & Warchalowski (2003) \\
\hline & & Chaetocnema & concinna (Marsham) & Roots, foliage & $\mathrm{X}$ & $\mathrm{Eu}, \mathrm{As}$ & $\begin{array}{l}\text { Doguet (1994); Cagán } \\
\text { et al. (2000); } \\
\text { Warchalowski (2003) }\end{array}$ \\
\hline & & Chaetocnema & tibialis (Illiger) & Roots, foliage & $\mathrm{X}$ & Med & Doguet (1994) \\
\hline & & Crepidodera & aurata (Marsham) & Foliage & $\mathrm{X}$ & $\mathrm{Eu}, \mathrm{As}$ & $\begin{array}{l}\text { A. Konstantinov, pers. } \\
\text { comm. }\end{array}$ \\
\hline & & Galeruca & pomonae (Scopoli) & rosettes & $\mathrm{X}$ & Ho & $\begin{array}{l}\text { Doguet (1994); } \\
\text { Steinhausen (1996) }\end{array}$ \\
\hline & & Galeruca & tanaceti $(\mathrm{L})$. & Foliage & $\mathrm{X}$ & $\mathrm{Eu}$ & $\begin{array}{l}\text { A. Konstantinov, pers. } \\
\text { comm. }\end{array}$ \\
\hline & & Longitarsus & brisouti Heikertinger & Foliage & $\mathrm{X}$ & $\mathrm{Eu}$ & $\begin{array}{l}\text { Doguet (1994); Biondi } \\
\text { (1996) }\end{array}$ \\
\hline & & Longitarsus & longipennis Kutschera & Roots, foliage & $\mathrm{X}$ & $\mathrm{Eu}, \mathrm{As}$ & $\begin{array}{l}\text { Biondi (1996); Cagán et al. } \\
(2000)\end{array}$ \\
\hline & & Longitarsus & luridus (Scopoli) & Bolting plants & $\mathrm{X}$ & $\mathrm{Pa}$ & $\begin{array}{l}\text { Doguet (1994); Biondi } \\
\text { (1996) }\end{array}$ \\
\hline & & Longitarsus & pratensis (Panzer) & Foliage & $\mathrm{X}$ & Med & $\begin{array}{l}\text { Doguet (1994); Biondi } \\
\text { (1996) }\end{array}$ \\
\hline & & Longitarsus & strigicollis Wollaston & $\begin{array}{l}\text { Bolting plants, } \\
\text { rosettes }\end{array}$ & G & Med & $\begin{array}{l}\text { Doguet (1994); Biondi } \\
\text { (1996) }\end{array}$ \\
\hline & & Neocrepidodera & ferruginea(Scopoli) & Foliage & $X$ & $\mathrm{Eu}, \mathrm{As}$ & Warchalowski (2003) \\
\hline & & Phyllotreta & nigripes (Fab.) & Roots, flowers & $\mathrm{X}$ & Med & $\begin{array}{l}\text { Doguet (1994); } \\
\text { Warchalowski (2003) }\end{array}$ \\
\hline & & Psyllioides & $\begin{array}{l}\text { circumdatus } \\
\text { (Redtenbacher) }\end{array}$ & Foliage & $\mathrm{X}$ & Med & $\begin{array}{l}\text { Doguet (1994); A. } \\
\text { Konstantinov, } \\
\text { pers. comm. }\end{array}$ \\
\hline & & Sermylassa & halensis (L.) & Foliage & $\mathrm{X}$ & $\mathrm{Eu}, \mathrm{As}$ & Warchalowski (2003) \\
\hline & & Smaragdina & limbata (Stéven) & Foliage & $\mathrm{X}$ & Med, As & $\begin{array}{l}\text { Gök (2002); A. } \\
\text { Konstantinov, } \\
\text { pers. comm. }\end{array}$ \\
\hline & & Smaragdina & xanthaspis (Germar) & Foliage & $\mathrm{X}$ & $\mathrm{Eu}, \mathrm{AM}$ & Warchalowski (2003) \\
\hline Diptera & Agromyzidae & Chromatomyia & ramosa (Hendel) & $\begin{array}{l}\text { Leaf miner, } \\
\text { rosettes }\end{array}$ & G & $\mathrm{Eu}$ & Hering (1957) \\
\hline \multirow[t]{2}{*}{ Hemiptera } & Coreidae & Coreus & marginatis (L.) & seeds? & $\mathrm{X}$ & $\mathrm{Eu}, \mathrm{As}$ & $\begin{array}{l}\text { Harizanova, unpublished } \\
\text { data }\end{array}$ \\
\hline & Miridae & Lygus & spp. & Foliage, heads & $\mathrm{X}$ & Co & $\begin{array}{l}\text { Harizanova, unpublished } \\
\text { data }\end{array}$ \\
\hline \multirow[t]{4}{*}{ Homoptera } & Aphididae & Myzus & persicae (Sulzer) & Foliage & $\mathrm{X}$ & $\mathrm{Co}$ & Stoner $(1951)$ \\
\hline & \multirow[t]{3}{*}{ Cercopidae } & Aphrophora & spp. & Rosettes & $\mathrm{X}$ & $\mathrm{Co}$ & $\begin{array}{l}\text { Harizanova, Rector and } \\
\text { Sforza, } \\
\text { unpublished data }\end{array}$ \\
\hline & & Cercopis & vulnerata Illiger & Foliage & $\mathrm{X}$ & $\mathrm{Co}$ & $\begin{array}{l}\text { Harizanova, Rector and } \\
\text { Sforza, } \\
\text { unpublished data }\end{array}$ \\
\hline & & Philaenus & spumarius (L.) & Foliage & $\mathrm{X}$ & $\mathrm{Ha}$ & $\begin{array}{l}\text { Harizanova, Rector and } \\
\text { Sforza, } \\
\text { unpublished data }\end{array}$ \\
\hline
\end{tabular}


Table 1 (continued)

\begin{tabular}{|c|c|c|c|c|c|c|c|}
\hline Order & Family & Genus & Species (author) & Damage & Specificity ${ }^{\mathrm{a}}$ & Range $^{\mathrm{c}}$ & Reference(s) \\
\hline \multirow[t]{4}{*}{ Hymenoptera } & Cimbicidae & Abia & sericea $(\mathrm{L})$. & Foliage & $\mathrm{X}$ & $\mathrm{Eu}, \mathrm{AM}$ & $\begin{array}{l}\text { André (1879); Taeger et al. } \\
\text { (1998); Magis (2001); } \\
\text { Liston (1995) }\end{array}$ \\
\hline & \multirow[t]{3}{*}{ Tenthredinidae } & Macrophya & $s p$. & Bolting plants & $\mathrm{U}$ & $\mathrm{Eu}, \mathrm{AM}$ & $\begin{array}{l}\text { Vassilev (1978); D. Smith, } \\
\text { pers. comm. }\end{array}$ \\
\hline & & Macrophya & diversipes (Schrank) & Unknown & $\mathrm{X}^{\mathrm{b}}$ & Med, As & Çalmasur and Özbek, 2004 \\
\hline & & Macrophya & postica (Brullé) & Unknown & $\mathrm{U}^{\mathrm{b}}$ & $\mathrm{Eu}, \mathrm{AM}$ & D. Smith, pers. comm. \\
\hline \multirow[t]{13}{*}{ Lepidoptera } & Adelidae & Nemophora & metallica (Poda) & Flowers, seeds & $\mathrm{X}$ & $\mathrm{Eu}$ & Novak et al. (1983) \\
\hline & \multirow[t]{2}{*}{ Arctiidae } & Diaphora & mendica (Clerck) & Foliage & $\mathrm{X}$ & $\mathrm{Pa}$ & $\begin{array}{l}\text { Koch (1984); Dubatolov } \\
\text { (1996) }\end{array}$ \\
\hline & & Rhyparia & purpurata $(\mathrm{L})$. & Foliage & $\mathrm{X}$ & $\mathrm{Pa}$ & $\begin{array}{l}\text { Koch (1984); Dubatolov } \\
\text { (1996) }\end{array}$ \\
\hline & Geometridae & Synopsia & sociaria (Hübner) & Foliage, bracts & $\mathrm{X}$ & $\mathrm{Eu}, \mathrm{As}$ & Koch (1984) \\
\hline & \multirow[t]{5}{*}{ Noctuidae } & Acronicta & rumicis (L.) & Foliage & $\mathrm{X}$ & $\mathrm{Eu}, \mathrm{As}$ & $\begin{array}{l}\text { Novak et al. (1983); Koch } \\
\text { (1984) }\end{array}$ \\
\hline & & Autographa & $\operatorname{gamma}(\mathrm{L})$. & Foliage & $\mathrm{X}$ & $\mathrm{Eu}, \mathrm{As}$ & M.G. Pogue, pers. comm. \\
\hline & & Heliothis & viriplaca (Hufnagel) & Foliage, seeds & $\mathrm{X}$ & $\mathrm{Eu}, \mathrm{As}$ & $\begin{array}{l}\text { Novak et al. (1983); Koch } \\
\text { (1984) }\end{array}$ \\
\hline & & Tyta & $\begin{array}{l}\text { luctuosa } \\
\text { (Den. and Schiff) }\end{array}$ & foliage & $\mathrm{X}$ & $\mathrm{Eu}$ & $\begin{array}{l}\text { Koch (1984); Rosenthal } \\
\text { et al. (1988) }\end{array}$ \\
\hline & & Xestia & c-nigrum (L.) & Foliage & $\mathrm{X}$ & $\mathrm{Ha}$ & $\begin{array}{l}\text { Koch (1984); Ferguson } \\
\text { et al. (1999) }\end{array}$ \\
\hline & Nymphalidae & Euphydryas & aurinia (Rottemburg) & $\begin{array}{l}\text { Rosettes, bolting } \\
\text { plants }\end{array}$ & $\mathrm{X}$ & $\mathrm{Eu}, \mathrm{AM}$ & $\begin{array}{l}\text { Mazel (1986); Wahlberg } \\
\text { (2001) }\end{array}$ \\
\hline & \multirow[t]{3}{*}{ Tortricidae } & Cochylis & roseana (Haworth) & Seeds & $\mathrm{X}$ & $\mathrm{Eu}, \mathrm{Med}$ & $\begin{array}{l}\text { Cheesman (1996); O. } \\
\text { Cheesman, } \\
\text { pers. comm. }\end{array}$ \\
\hline & & Endothenia & gentianaeana (Hübner) & head cavity & $\mathrm{X}$ & $\mathrm{Eu}, \mathrm{As}$ & $\begin{array}{l}\text { Gibeaux (1988); } \\
\text { Cheesman (1996); } \\
\text { Trematerra and } \\
\text { Baldizzone (2004) }\end{array}$ \\
\hline & & Endothenia & oblongana (Haworth) & Root crown, stalk & $\mathrm{X}$ & $\mathrm{Eu}$ & $\begin{array}{l}\text { Gibeaux (1988); } \\
\text { Trematerra and } \\
\text { Baldizzone (2004) }\end{array}$ \\
\hline \multicolumn{8}{|l|}{ Viruses } \\
\hline Virus & Unknown & Unknown & unknown & $\begin{array}{l}\text { Symptoms at } \\
\text { bolting }\end{array}$ & $\mathrm{U}$ & $\mathrm{Eu}$ & $\begin{array}{l}\text { Rector and Widmer, } \\
\text { unpublished data (see text) }\end{array}$ \\
\hline
\end{tabular}

\footnotetext{
a Specificity index: X, not specific to Dipsacaceae; G, only known from Dipsacaceae, including the genus Dipsacus; S, only known from Dipsacus spp.; and $\mathrm{U}$, unknown.

b Species possibly accidental; not found feeding on Dipsacus.

c AM, Asia minor; As, Asia; Co, cosmoplitan; Eu, Europe; Ha, Holarctic; Med, Mediterranean; NA, North America; Pa, Palearctic; and U, unknown.
}

include host specificity testing for potential non-target plants in the proposed region of release followed by mass-rearing and redistribution of the $\mathrm{BCC}$ in the release area, assuming favorable host specificity test results. This would be similar to a classical augmentation biological control strategy (Pedigo, 1989) unless this moth currently shows only a restricted distribution in the USA with respect to the target. There may also be Old World insects that have been introduced into N. America that feed on teasels. The polyphagous European chrysomelid flea beetle Longitarsus luridus (Scopoli), which has been collected by the authors in the adult stage feeding on teasel foliage in Bulgaria and Romania, has been reported by Doguet (1994) as accidentally introduced into $\mathrm{N}$. America. There are, however, no reports of it feeding on teasels there. Although $L$. luridus itself is not a very suitable BCC due to its highly polyphagous habit, there may be other accidentally introduced teasel-feeding insects that could be more interesting. Indeed, precedents for such serendipidous biological control agents exist (e.g., McClay, 1990).

In addition to these herbivores, Stoner (1951) described a virus attacking cultivated teasel (D. sativus) rosettes in central California. He found that it was nonpersistently transmitted by both Myzus persicae (Sulzer) and Macrosiphum rosae (L.) and in a test of several horticulturally important plant species, the virus would only attack teasel and Scabiosa atropurpurea L., an ornamental Dipsacaceae that has been introduced to the US (Bailey, 1951). A survey of the area near this virus's discovery, and perhaps an intentional planting of one or more small fields of teasels in an attempt to "trap" this virus could be worthwhile. Additional general surveys for herbivores in the invaded range are needed to further assess the possible presence of BCCs that may already exist in N. America. 
Table 2

Invertebrate herbivores and pathogens associated with plant species in the family Dipsacaceae that have not been collected by the authors

\begin{tabular}{|c|c|c|c|c|c|c|c|}
\hline Order & Family & Genus & Species (author) & Damage & Specificity $^{\mathrm{a}}$ & Range $^{\mathrm{b}}$ & Reference(s) \\
\hline \multicolumn{8}{|l|}{ Fungi } \\
\hline Agnomycetales & Agnomycetaceae & Sclerotium & rolfsii Sacc. & Root, stem & $\mathrm{X}$ & NA & Farr et al. (2004) \\
\hline \multirow[t]{3}{*}{ Dothideales } & Dothideaceae & Didymella & exigua (Niessl) Sacc. & Stem, foliage & $\mathrm{X}$ & $\mathrm{Co}$ & Farr et al. (2004) \\
\hline & & Ramularia & silvestris Sacc. & Foliage & $\mathrm{S}$ & NA & Farr et al. (2004) \\
\hline & Hysteriaceae & Clathrospora & permunda (Cooke) Sacc. & Foliage & $\mathrm{X}$ & Ho & Farr et al. (2004) \\
\hline \multirow[t]{7}{*}{ Erysiphales } & Erysiphaceae & Erysiphe & cichoracearum DC & Stem, foliage & $\mathrm{X}$ & $\mathrm{Co}$ & Farr et al. (2004) \\
\hline & & Erysiphe & communis (Wallr.) Link & Stem, foliage & $\mathrm{X}$ & $\mathrm{Eu}$ & Farr et al. (2004) \\
\hline & & Erysiphe & galeopsidis DC & Stem, foliage & $\mathrm{X}$ & As & Farr et al. (2004) \\
\hline & & Erysiphe & knautiae Duby & Stem, foliage & G & $\mathrm{Eu}$ & Farr et al. (2004) \\
\hline & & Phyllactinia & guttata (Wallr.) Lév. & Foliage & $\mathrm{X}$ & Ho & Farr et al. (2004) \\
\hline & & Sphaerotheca & $\begin{array}{l}\text { dipsacearum (Tul. and } \\
\text { C. Tul.) }\end{array}$ & Foliage & G & $\mathrm{Eu}$ & Farr et al. (2004) \\
\hline & & Sphaerotheca & $\begin{array}{l}\text { fuliginea (Schlect.) } \\
\text { Pollacci }\end{array}$ & Foliage & $\mathrm{X}$ & $\mathrm{Co}$ & Farr et al. (2004) \\
\hline Melanommatales & Didymosphaeriaceae & Diapleella & clivensis (Berk. \& Broome) & Foliage & $\mathrm{X}$ & NA & Farr et al. (2004) \\
\hline \multirow[t]{3}{*}{ Moniliales } & Dematiaceae & Cercospora & elongata Peck & Foliage & $\mathrm{S}$ & As, NA & Farr et al. (2004) \\
\hline & & Fusariella & hughesii Chab.-Frydm & Foliage & $\mathrm{X}$ & $\mathrm{Co}$ & Farr et al. (2004) \\
\hline & Moniliaceae & Phymatotrichum & omnivorum Duggar & Foliage & $\mathrm{X}$ & NA & Farr et al. (2004) \\
\hline Mycosphaerellales & Mycosphaerellaceae & Sphaerella & asterinoides Ellis \& Everh. & Stem, foliage & $\mathrm{S}$ & $\mathrm{Eu}, \mathrm{NA}$ & Farr et al. (2004) \\
\hline Peronosporales & Peronosporaceae & Peronospora & dipsaci Tul. ex de Bary & Stem, foliage & G & $\mathrm{Eu}, \mathrm{As}, \mathrm{NA}$ & Farr et al. (2004) \\
\hline \multirow[t]{5}{*}{ Pleosporales } & Pleosporaceae & Leptosphaeria & conoidea (De Not.) Sacc. & Root, stem & $\mathrm{X}$ & NA & Farr et al. (2004) \\
\hline & & Pleospora & herbarum (Fr.) Rabenh. & Foliage & $\mathrm{X}$ & $\mathrm{Eu}, \mathrm{As}$ & Farr et al. (2004) \\
\hline & & Pleospora & $\begin{array}{l}\text { scrophulariae (Desm.) } \\
\text { Höhn }\end{array}$ & Foliage & $\mathrm{X}$ & As, NA & Farr et al. (2004) \\
\hline & & Pleospora & vulgaris Niessl & Foliage & $\mathrm{X}$ & As & Farr et al. (2004) \\
\hline & Venturiaceae & Venturia & $\begin{array}{l}\text { cephalariae Kalchbr.\& } \\
\text { Cooke }\end{array}$ & Foliage & G & As & Farr et al. (2004) \\
\hline \multirow[t]{2}{*}{ Sphaeropsidales } & Sphaeropsidaceae & Ascochyta & dipsaci Bubák & foliage & G & $\mathrm{Eu}$ & Farr et al. (2004) \\
\hline & & Phoma & $\begin{array}{l}\text { oleracea var. dipsaci } \\
\text { Sacc. }\end{array}$ & $\begin{array}{l}\text { Crown, root, } \\
\text { foliage }\end{array}$ & S & NA & Farr et al. (2004) \\
\hline \multicolumn{8}{|l|}{ Mites } \\
\hline \multirow[t]{2}{*}{ Acarina } & Eriophyidae & Aceria & squalida (Nat.) & Flowers & $\mathrm{F}$ & $\mathrm{Eu}$ & $\begin{array}{l}\text { Petanovic and } \\
\text { Stankovic (1999) }\end{array}$ \\
\hline & & Epitrimerus & knautiae Liro & Flower galls? & G & $\mathrm{Eu}$ & Petanovic (2001) \\
\hline
\end{tabular}

Insects

Coleoptera

$\begin{array}{ll}\text { Buprestidae } & \text { Trachys } \\ & \text { Trachys } \\ \text { Chrysomelidae } & \text { Longitarsus }\end{array}$

puncticollis Obenberger

Leaf miner troglodytes Gyllenhal allotrophus Furth

Leaf miner

Foliage

X
F
X
S

F
X
X
F
F
G
X
F
X

Agromyzidae

Agromyza

dipsaci Hendel

Leaf miner,

bolting plants

Agromyza woerzi Groschke

Aulagromyza

similis (Brischke)

Chromatomyia

horticola (Goureau)

Chromatomyia

scabiosae (Hendel)

Chromatomyia

Chromatomyia

scabiosarum (de Meijere)

Liriomyza

Homoptera

Aphididae

Aphis

knautiae Hering

Leaf miner

Leaf miner

leaf miner

Leaf miner

Leaf miner

Lleaf miner

Leaf miner

leaf miner

Foliage

confusa Walker

Aphis
Aphis
Aphis
Aphis
Aphis
Macrosiphum
Macrosiphum
Abia

foliage

Foliage

Foliage

ochropus Koch

Foliage

foliage

scabiosae Schrank

rosae (L.)

rudbeckiae Fitch

Foliage

Foliage

Foliage

$\mathrm{Eu}$

Curletti (1994)

Hering (1957)

Doguet (1994);

Biondi (1996)

Hering (1957)

Hering (1957)

Hering (1957)

Hering (1957)

Hering (1957)

Hering (1957)

Hering (1957)

Hering (1957)

Hering (1957)

Patch (1938);

Briese (1989)

Patch (1938)

Patch (1938)

Patch (1938)

Patch (1938)

Patch (1938)

Patch (1938)

Patch (1938)

Taeger et al.

(1998); Magis (2001) 
Table 2 (continued)

\begin{tabular}{|c|c|c|c|c|c|c|c|}
\hline Order & Family & Genus & Species (author) & Damage & Specificity $^{\mathrm{a}}$ & Range $^{b}$ & Reference(s) \\
\hline & & Abia & fasciata $(\mathrm{L})$. & Foliage & $\mathrm{X}$ & $\mathrm{Eu}$ & Magis (2001) \\
\hline & & Abia & lonicerae (L.) & Foliage & $\mathrm{X}$ & $\mathrm{Eu}$ & Chevin (2001); \\
\hline & Tenthredinidae & Macrophya & albicincta (Schrank) & Foliage & $\mathrm{X}$ & Med, As & Magis (2002); \\
\hline & & & & & & & $\begin{array}{l}\text { Çalmasur and } \\
\text { Özbek, } 2004\end{array}$ \\
\hline & & Macrophya & crassula (Klug) & Foliage & $\mathrm{X}$ & $\mathrm{Eu}, \mathrm{AM}$ & Magis (2002); \\
\hline & & & & & & & $\begin{array}{l}\text { Çalmasur and } \\
\text { Özbek (2004) }\end{array}$ \\
\hline & & Tenthredo & atra $\mathrm{L}$. & Foliage & $X$ & $\mathrm{Eu}, \mathrm{As}$ & André (1879); \\
\hline & & & & & & & Lacourt (1999) \\
\hline \multirow[t]{30}{*}{ Lepidoptera } & Arctiidae & Artimelia & latreillei (Godart) & Foliage & $\mathrm{X}$ & $\mathrm{Eu}$ & $\begin{array}{l}\text { de Freina and } \\
\text { Witt (1987) }\end{array}$ \\
\hline & & Ocnogyna & parasita(Hübner) & foliage & $\mathrm{X}$ & $\mathrm{Eu}, \mathrm{As}$ & $\begin{array}{l}\text { de Freina and } \\
\text { Witt (1987) }\end{array}$ \\
\hline & Coleophoridae & Coleophora & conspicuella Zeller & Foliage & $\mathrm{X}$ & $\mathrm{Eu}, \mathrm{As}$ & Hering (1957) \\
\hline & & Coleophora & paripennella Zeller & Foliage & $\mathrm{X}$ & $\mathrm{Eu}$ & Hering (1957) \\
\hline & Gracillariidae & Phyllonorycter & scabiosella (Douglas) & Leaf miner & $\mathrm{F}$ & $\mathrm{Eu}$ & $\begin{array}{l}\text { Emmet et al. } \\
\text { (1985) }\end{array}$ \\
\hline & Noctuidae & Eriopygodes & imbecilla (Fab.) & Foliage & $\mathrm{X}$ & $\mathrm{Eu}, \mathrm{As}$ & $\begin{array}{l}\text { Novak et al. } \\
\text { (1983) }\end{array}$ \\
\hline & & Nola & chlamitulalis (Hübner) & foliage & $\mathrm{X}$ & Med, As & $\begin{array}{l}\text { de Freina and } \\
\text { Witt (1987) }\end{array}$ \\
\hline & & Papaipema & arctivorens Hampson & Root & $\mathrm{X}$ & NA & $\begin{array}{l}\text { Hodges (1983); } \\
\text { Covell (1984) }\end{array}$ \\
\hline & Nymphalidae & Euphydryas & desfontainii (Godart) & $\begin{array}{l}\text { Rosettes, bolting } \\
\text { plants }\end{array}$ & G & $\mathrm{Eu}$ & $\begin{array}{l}\text { Nóvoa Pérez } \\
\text { and García- } \\
\text { Villanueva } \\
\text { (1996); } \\
\text { Wahlberg (2001) }\end{array}$ \\
\hline & Oecophoridae & Agonopterix & arenella (Den. and Schiff.) & foliage & $\mathrm{X}$ & Med, NA & $\begin{array}{l}\text { Novak et al. } \\
\text { (1983); Harper } \\
\text { et al. (2002) }\end{array}$ \\
\hline & & Agonopterix & kaekeritziana (L.) & Foliage & $\mathrm{X}$ & $\mathrm{Eu}$ & $\begin{array}{l}\text { Novak et al. } \\
\text { (1983) }\end{array}$ \\
\hline & Papillionidae & Parnassius & apollonius (Eversman) & Foliage & $\mathrm{X}$ & As & $\begin{array}{l}\text { Novak et al. } \\
\text { (1983) }\end{array}$ \\
\hline & Psychidae & Apterona & helicoidella (Vallot) & Foliage & $\mathrm{X}$ & $\mathrm{Eu}$ & $\begin{array}{l}\text { Hering (1957); } \\
\text { Novak et al. } \\
\text { (1983) }\end{array}$ \\
\hline & Pterophoridae & Gillmeria & miantodactylus Zeller & Foliage, flowers & $\mathrm{F}$ & $\mathrm{Eu}$ & Gielis (1996) \\
\hline & & Stenoptilia & annadactyla Sutter & Foliage, flowers & $\mathrm{F}$ & $\mathrm{Eu}$ & Gielis (1996) \\
\hline & & Stenoptilia & aridus (Zeller) & Foliage, flowers & $\mathrm{X}$ & Med & Gielis (1996) \\
\hline & & Stenoptilia & bipunctidactyla (Scopoli) & Foliage, flowers & $\mathrm{X}$ & $\mathrm{Eu}$ & Gielis (1996) \\
\hline & & Stenoptilia & stigmatodactylus (Zeller) & Foliage, flowers & $\mathrm{X}$ & Med & Gielis (1996) \\
\hline & Scythrididae & Scythris & picaepennis (Haworth) & leaf miner & $\mathrm{X}$ & $\mathrm{Eu}, \mathrm{As}$ & $\begin{array}{l}\text { Hering (1957); } \\
\text { Bengtsson } \\
(1997)\end{array}$ \\
\hline & & Scythris & siccella (Zeller) & Leaf miner & $\mathrm{X}$ & $\mathrm{Eu}$ & Hering (1957) \\
\hline & Sphingidae & Acherontia & athropos (L.) & Foliage & $\mathrm{X}$ & Af, Eu & Pittaway (1993) \\
\hline & & Hemaris & croatica (Esper) & Foliage & $\mathrm{X}$ & $\mathrm{Eu}, \mathrm{AM}$ & Pittaway (1993) \\
\hline & & Hemaris & fuciformis (L.) & Foliage & $\mathrm{X}$ & $\mathrm{Eu}, \mathrm{As}$ & Pittaway (1993) \\
\hline & & Hemaris & tityus (L.) & Foliage & $\mathrm{X}$ & $\mathrm{Eu}, \mathrm{As}$ & Pittaway (1993) \\
\hline & & Hyles & livornica (Esper) & Foliage & $\mathrm{X}$ & Af, Eu, As & Pittaway (1993) \\
\hline & Tortricidae & Aethes & hartmanniana (Clerck) & Root, crown & $\mathrm{F}$ & $\mathrm{Eu}$ & $\begin{array}{l}\text { Razowski } \\
(1970) ; \\
\text { Trematerra and } \\
\text { Baldizzone } \\
(2004)\end{array}$ \\
\hline & & Cnephasia & incertana (Treitscke) & Foliage & $\mathrm{X}$ & $\mathrm{Eu}$ & Hering (1957) \\
\hline & & Cnephasia & stephensiana (Doubleday) & Foliage & $\mathrm{X}$ & $\mathrm{Eu}$ & Hering (1957) \\
\hline & & Cochylimorpha & straminea (Haworth) & Flower buds, seeds & $\mathrm{X}$ & Eu, Med & $\begin{array}{l}\text { Novak et al. } \\
(1983)\end{array}$ \\
\hline & & Cochylis & flaviciliana (Westwood) & Flower buds, seeds & G & Eu, Med & Razowski (1970) \\
\hline
\end{tabular}


Table 2 (continued)

\begin{tabular}{|c|c|c|c|c|c|c|c|}
\hline Order & Family & Genus & Species (author) & Damage & Specificity $^{\mathrm{a}}$ & Range $^{b}$ & Reference(s) \\
\hline & & Diceratura & ostrinana (Guenée) & Immature flowers & $\mathrm{X}$ & $\mathrm{Eu}, \mathrm{AM}$ & $\begin{array}{l}\text { Razowski } \\
\text { (1970); Gibeaux } \\
\text { (1988) }\end{array}$ \\
\hline & & Endothenia & marginana (Haworth) & Head cavity, seeds & $\mathrm{X}$ & $\mathrm{Eu}$ & $\begin{array}{l}\text { Gibeaux (1988); } \\
\text { Trematerra and } \\
\text { Baldizzone } \\
(2004)\end{array}$ \\
\hline & & Rhopoboda & stagnana (Den. and Schiff.) & Leaf miner & $\mathrm{F}$ & $\mathrm{Eu}$ & Hering (1957) \\
\hline \multicolumn{8}{|l|}{ Nematodes } \\
\hline Tylenchida & Anguinidae & Ditylenchus & dipsaci Filipjev & Roots & $\mathrm{X}$ & $\mathrm{Ha}$ & Thorne (1945) \\
\hline \multicolumn{8}{|l|}{ Viruses } \\
\hline Virus & Potyviridae? & $? ?$ & $? ?$ & $\begin{array}{l}\text { Symptoms in } \\
\text { rosettes }\end{array}$ & G & NA & Stoner (1951) \\
\hline
\end{tabular}

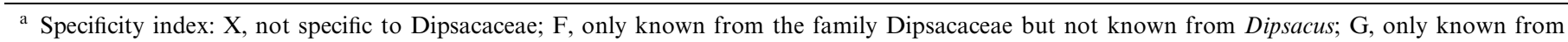
Dipsacaceae, including the genus Dipsacus; S, only known from Dipsacus spp.; and U, unknown.

b Af, Africa; AM, Asia Minor; As, Asia; Co, cosmoplitan; Eu, Europe; Ha, Holarctic; Med, Mediterranean; NA, North America; and U, unknown.

\subsection{Candidates from the native range of D. fullonum and D. laciniatus}

Despite the long history of teasel cultivation in Europe and the United States, there is very little reference in the scientific literature to teasel pests, beside the virus described by Stoner (1951) and a reference to the "teasel fly," Chromatomyia ramosa (Hendel) (Diptera: Agromyzidae), which was considered an important enough pest in England to merit regularly scheduled sprays of malathion or DDT (Topham, 1968). This insect was reared from mines in $D$. fullonum rosette leaves from France and Greece in the spring of 2004. The insect is bivoltine with a larval generation from May to August and another from October to April and it is also reported to feed on new growth at the center of the rosette late in the larval stage (Hering, 1957). This insect's host range is limited to the family Dipsacaceae (Hering, 1957) and three congeners: C. scabiosae (Hendel); C. scabiosarum (de Meijere); and C. succisae (Hering) are also only known to feed on Dipsacaceae (Hering, 1957). Another agromyzid leaf mining fly, Agromyza dipsaci Hendel, has also only been described feeding on $D$. fullonum (Hering, 1957). D. fullonum leaves collected in France in the summer of 2004 were observed to have damage similar to that of $A$. dipsaci as illustrated by Hering (1957), although it was too late in the season to collect insects from these leaves. This species is univoltine with the larval feeding occurring in May and June along the margins of the stem leaves of bolted plants.

A tortricid seed-feeder, Cochylis roseana (Haworth), has been well-documented from D. fullonum (Cheesman, 1996) and larvae matching this species's description have been collected from seedheads of $D$. laciniatus in Bulgaria. Female moths lay clusters of eggs at the bases of involucral bracts on young teasel flowerheads, whereupon hatched larvae enter the head and begin feeding on florets and developing seeds before switching exclusively to seeds (Cheesman, 1996). Larvae of this species feed gregariously and Cheesman (1996) reported an average of more than 18 larvae per head. They overwinter in the seedhead as larvae before pupating in the spring and emerging as adults shortly thereafter. This species is also known to attack Solidago spp., a group outside the order Dipsacales of which there are several N. American species. This fact would complicate host-specificity testing on $C$. roseana. A congener, $C$. flaviciliana (Westwood) could be a more promising candidate. It has been reported from teasel flowerheads and its host-range is only known to include plants in the Dipsacaceae (Table 2). However, $C$. flaviciliana has not yet been collected by the authors. Another congener ( $C$. hospes Walsingham) is a known pest of sunflower (Barker, 1996), while another [C. atricapitana (Stephens)] has been released as a biological control agent against Senecio jacobaeae L. in Australia (McLaren, 1992).

Larvae of two species in the nymphalid genus Euphydryas Scudder, E. aurinia (Rottemburg) and E. desfontainii (Godart), are known to feed on Dipsacus spp. (Mazel, 1986; Wahlberg, 2001). E. aurinia has been encountered in the field in several countries across Europe from France to Turkey (Sforza, 2004). However, this gregarious feeder also feeds on host plants in at least three families, including one (Gentianaceae) outside the order Dipsacales (Wahlberg, 2001). The native range of $E$. desfontainii covers most of the Iberian peninsula, parts of N. Africa and isolated populations in SW France, where it is a protected species. Its hostrange appears to be narrower than that of E. aurinia, feeding only on plants in the Dipsacaceae (Wahlberg, 2001). Females of both of these species lay groups of eggs on the host plant in May and June. The larvae hatch soon after and feed briefly, completing early instars before aestivating until autumn. The larvae may feed again in autumn before hibernating until early spring when they complete feeding, pupate, and emerge as adults.

Longitarsus strigicollis Wollaston is a chrysomelid flea beetle that has been found feeding in large numbers on D. fullonum in France and Italy. This species is found in the adult stage whenever the weather is warm enough and it is thought for this reason to be multivoltine in warmer 
climates (Doguet, 1994). The adults of this species are only known to feed on hosts in the Dipsacaceae (Doguet, 1994) but the larval stage is as yet undescribed. Based on information about the larval habits of congeneric species (Steinhausen, 1996), it is believed the larvae of L. strigicollis may be external root feeders of Dipsacaceae, overwintering in the soil as immatures. This hypothesis is currently being tested.

The cerambycid stalk borer Agapanthia osmanlis Reiche feeds only on hosts in the Dipsacaceae (Kovacs, 1998; Rejzek et al., 2003) and has been collected on Dipsacus spp. in Bulgaria and Turkey. Adults of this species are active in the spring and summer and feed on the foliage of bolting plants. The female lays single eggs inside teasel stalks where the larva feeds internally. After overwintering, the insect pupates in the spring before emerging as an adult in summer. Tests are underway to determine whether the larval feeding causes damage early enough in the plant's life to significantly affect seed production.

Larvae of the cimbicid sawfly Abia sericea (L.) were found feeding on D. laciniatus in Bulgaria and Turkey. This species has been described from several hosts in the Dipsacaceae but also from Fragaria sp. (strawberries) (Liston, 1995). Tests are currently underway to investigate the validity of this report, since it would represent the only known host record for a European Abia sp. from outside the Dipsacaceae or the closely related Caprifoliaceae (Taeger et al., 1998). Indeed, as Taeger et al. (1998) state explicitly, "under field conditions Fragaria is surely not a host plant (of $A$. sericea)." The congener $A$. candens Konow, is only known from Dipsacaceae (see Table 2).

The eriophyid mite Epitrimerus knautiae Liro has been collected from flower galls of D. laciniatus in Yugoslavia (Petanovic, 1999; R. Petanovic, pers. comm.). It is not clear whether these mites caused the galls within which they were found (R. Petanovic, pers. comm.). The only other reports of this mite list it as vagrant on leaves of Knautia arvensis (L.) Coulter, a close relative of Dipsacus, in Finland (Liro, 1942) and Poland (Boczek, 1964).

Several fungi have been collected from Dipsacus spp. and shown to be primary pathogens of D. fullonum (see Table 1). Among these, Sclerotinium sclerotiorum (Lib.) de Bary may hold promise as a mycoherbicide, although it has a broad host range. Attenuated mutants of this species have been proposed for control of Cirsium arvense (L.) Scop. in the US (Brosten and Sands, 1986) and Chrysanthemoides monilifera (L.) T.Nord in Australia (Cother et al., 1996). Depending on the success of $S$. sclerotiorum in being approved for release and in controlling these or other targets, $D$. fullonum and $D$. laciniatus could become new targets for this mycoherbicide.

In addition to the three fungi that the authors have collected on Dipsacus in the field (Table 1), reports of 24 other fungi associated with Dipsacus spp. are cataloged in the USDA-ARS GRIN database (Farr et al., 2004) (Table 2). Although some genera of these fungi are known to have broad host ranges, individual isolates may show higher specificity. Thus, it is important to isolate fungi from teasels and conduct further tests from these specific isolates on a case-by-case basis. As we found little work has been done on any of the fungi listed in Table 2, it cannot be said with certainty what potential any of these fungi have as BCCs. Exploration and research remains to be conducted to collect and evaluate individual fungal isolates for host specificity and impact.

In addition to the four fungal species listed in Table 2 as specific to Dipsacus (all of which are based on only a few reports per fungal species), two powdery mildews (family Erysiphaceae), have potential as promising BCCs from the standpoint of specificity, although their impact on the plant is not yet known. Sphaerotheca dipsacearum (Tul and C. Tul) has 58 host records in the GRIN database from seven host genera, all of which are in the Dipsacaceae (Farr et al., 2004). For Erysiphe knautiae Duby, only two of the 221 host records in the GRIN database fall outside the Dipsacaceae (Papaver anomalum Fedde. and Saxifraga manchuriensis (Engler) Komarov) (Farr et al., 2004). These plant species would need to be tested in any subsequent host specificity testing.

Symptoms of an as yet unidentified virus have been observed on $D$. fullonum in southern France and similar symptoms have been observed on D. fullonum and D. laciniatus in Bulgaria, northern France, Slovenia, and Turkey. This virus causes mosaic-like, chlorotic symptoms in bolting plants, followed by stunting and discoloration of the mature plant. These symptoms are quite unlike those of the teasel virus described by Stoner (1951). Field observations of tagged plants with viral symptoms indicate a significant reduction in number of seedheads per plant, as well as a proportion of plants that produce no seed at all (Rector, unpublished data). Work is under way to identify this virus and to determine how it is vectored from one generation to the next.

\section{Risk assessment and potential interactions of biological control candidates}

As BCCs are prioritized for further work, host-specificity test plant lists need to be agreed upon. As agents with narrow host ranges tend to be restricted to related host plants (Wapshere, 1974), phylogenetic clade information to develop these lists from recent molecular phylogenies should be used (Briese, 2002). For Dipsacales, three recent molecular phylogenetic treatments (Bell et al., 2001; Donoghue et al., 2001; Zhang et al., 2003) are all in general agreement and should assist this.

Potential interactions between the aforementioned highpriority BCCs have not yet been evaluated. Any competitive or synergistic interactions between multiple BCCs approved for release can be tested before their respective introductions since no teasel biological control agents have yet been released and there currently appears to be little natural enemy activity on teasel in N. America. Priority for study of subsequent BCCs should however be given to 
candidates attacking different plant parts from the first released agents, as advocated by Malecki et al. (1993) and others.

\section{Conclusions}

As invasive teasels continue to spread in the US, particularly on lands that are not intensively managed for weed control, the need for a self-sustaining management strategy, such as biological control, increases. Teasels present particular opportunities as biological control targets, given the absence of any North American relatives or economically important plants within the family. In their native ranges, $D$. fullonum and $D$. laciniatus rarely achieve the population sizes or densities that have induced five American states to list either or both as noxious species. Whether natural enemies of these teasels are responsible for keeping native populations in check is not known, however based on the results of the initial literature and field surveys presented in this article, it appears that natural enemies of Dipsacus spp. are both numerous and specific enough to yield promising biological control agents that could suppress invasive populations.

Among the BCCs collected and identified to date, the highest priority for initial study has been assigned to two insects that attack the first-year vegetative rosette stage of teasel. Damage at this stage appears to be the most promising for biological control since it could delay flowering from one summer to the next and perhaps prevent it altogether. These two insect species are the chrysomelid flea beetle $L$. strigicollis, which feeds on foliage as an adult and may also feed on roots in the larval stage and the agromyzid fly $C$. ramosa, which mines rosette leaves and may feed at the apical meristem late in larval development. Among those BCCs identified in the literature but not yet observed or collected by the authors in the field, those to which the authors assign the highest priority for targeted surveys include the foliage-feeding nymphalid butterfly Euphydryas desfontainii, the eriophyid mite E. knautiae, the root-boring noctuid moth $P$. arctivorens, an aphid-transmitted virus described from California (Stoner, 1951), and the powdery mildews $E$. knautiae and $S$. dipsacearum.

\section{Acknowledgments}

The authors thank Randy Heidorn of the Illinois Nature Preserves Commission; Benoit Nusillard and Olivier Simonot of EBCL-Montpellier, and Javid Kashefi of EBCLThessaloniki for their assistance in this project. The following scientists provided insect identifications, without which this article would not have been possible: J.W. Brown (Lepidoptera), A.S. Konstantinov (Coleoptera), A.L. Norrbom (Diptera), M.G. Pogue (Lepidoptera), D.R. Smith (Hymenoptera), and N.E. Woodley (Diptera) of USDA-ARS, Systematics Entomology Laboratory; as well as C. Cocquempot and M. Martinez, INRA, Montpellier, France; M-S. Garcin, Agro-M, Montpellier, France; and
R. Beenen, Nieuwegein, Netherlands. Drs. Brown, Konstantinov, Martinez, and Smith have also provided other helpful information. Martin Rejzek of Norfolk, UK, provided a brief description of the $A$. osmanlis life-cycle.

\section{References}

André, E., 1879. Species des Hyménoptères d'Europe et d'Algérie. vol. 1, Beaune, France.

Andrieu-Ponel, V., Ponel, P., de Beaulieu, J.-L., Bruneton, H., Leveau, P., 2000. Paleoenvironments and cultural landscapes of the last 2000 years reconstructed from pollen and Coleopteran records in the Lower Rhône Valley, southern France. Holocene 10, 341-355.

Bailey, L.H., 1951. Manual of Cultivated Plants. Macmillan, NY.

Barker, J.F., 1996. The biology and management of the banded sunflower moth, Cochylis hospes: past, present, and future. In: Proceedings of the Ninth Great Plains Sunflower Insect Workshop, pp. 74-88.

Beaton, L.L., Dudley, S.A., 2004. Tolerance to salinity and manganese in three common roadside species. Int. J. Plant Sci. 165, 37-51.

Bell, C.D., Edwards, E.J., Kim, S.T., Donoghue, M.J., 2001. Dipsacales phylogeny based on chloroplast DNA sequences. Harvard Pap. Bot. 6, 481-499.

Bengtsson, B.Å., 1997. Scythrididae. In: Huemer, P., Karsholt, O., Lyneborg, L. (Eds.), Microlepidoptera of Europe 2. Apollo Books, Stenstrup, Denmark, pp. 1-301.

Biondi, M., 1996. Proposal for an ecological and zoogeographical categorization of the Mediterranean species of the flea beetle genus Longitarsus Berthold. In: Jolivet, P.H.A., Cox, M.L. (Eds.), Chrysomelidae Biology, vol. 3: General Studies. SPB Academic Publishing, Amsterdam, pp. 13-35.

Blossey, B., 1995. A comparison of various approaches for evaluation potential biological control agents using insects on Lythrum salicaria. Biol. Control 5, 113-122.

Bobrov, E.G., 1957. Genus 1411. Dipsacus L.. In: Shishkin, B.K., Bobrov, E.G. (Eds.), Flora of the U.S.S.R. vol. 24, Dipsacaceae, Cucurbitaceae, Campanulaceae. Izdarel'stvo Akademii Naulk SSR, Moscow-Leningrad, pp. 16-20.

Boczek, J., 1964. Studies on Mites (Acarina) Living on Plants in Poland. V. Bulletin de L'Academie Polonaise des Sciences ClV 12, 391-398.

Briese, D.T., 1989. Host-specificity and virus-vector potential of Aphis chloris (Homoptera: Aphididae), a biological control agent for St. John's wort in Australia. Entomophaga 34, 247-264.

Briese, D.T., 2002. The centrifugal phylogenetic method used to select plants for host-specificity testing of wedd biological control agents: Can and should it be modernised? In: Jacob, H.S., Briese, D.T. (Eds.), Improving the Selection, Testing, and Evaluation of Weed Biological Control Agents. Proceedings of the CRC for Australian Weed Management Biological Control of Weeds Symposium and Workshop, pp. 23-33.

Brosten, B.S., Sands, D.C., 1986. Field trials of Sclerotinia sclerotiorum to control Canada Thistle (Cirsium arvense). Weed Sci. 34, 377-380.

Cagán, L., Vráblová, M., Tóth, P., 2000. Flea beetles (Chrysomelidae: Alticinae) species occurring on Amaranthus spp. in Slovakia. JCEA 1, $1-10$.

Çalmasur, Ö, Özbek, H., 2004. A contribution to the knowledge of the Tenthredinidae (Symphyta, Hymenoptera) fauna of Turkey. Part 1: The subfamily Tenthredininae. Turk. J. Zool. 28, 37-54.

Cheesman, O.D., 1996. Life histories of Cochylis roseana and Endothenia gentianaeana (Lepidoptera: Tortricidae) on wild teasel. Entomologist $115,65-80$.

Cheesman, O.D., 1998. The impact of some field boundary management practices on the development of Dipsacus fullonum L. flowering stems, and implications for conservation. Agric. Ecosyst. Environ. 68, 41-49.

Chevin, H., 2001. Biologie et description de la larve de Zaraea lonicerae (L.) (Hymenoptera, Cimbicidae). Cahiers de Naturalistes. Bull. des N.P. (N.S.) 54, $1-4$.

Chuko, H., Hanyu, Y., 1990. Growth characteristics of teasel (Dipsacus fullonum L.). Jpn. J. Crop Sci. 59, 461-468. 
Cother, E.J., Nikandrow, A., Gilbert, R.L., 1996. Sclerotinia sclerotiorum as a potential biocontrol agent for Chrysanthemoides monilifera (bitoubush). In: Moran, V.C., Hoffman, J.H. (Eds.), Proceedings of the Ninth International Symposium on Biological Control of Weeds. University of Cape Town, Stellenbosch, South Africa, pp. 529-530.

Covell Jr., C.V., 1984. A Field guide to the Moths of Eastern North America. Houghton Mifflin, Boston.

Curletti, G., 1994. I Buprestidi d'Italia, Catalogo geonomico, sinonimico, bibliografico, biologico. Mon. Nat. Bresciana, No. 19., Vannini, Breschia.

Darwin, C., 1859. The Origin of Species by Means of Natural Selection; Chapter 1: Variation Under Domestication. Penguin Books, New York, p. 89.

Doguet, S., 1994. Faune de France. Coléoptères Chrysomelidae 2. Alticinae, Fédération Française des Sociétés de Science Naturelles, Paris.

Donoghue, M.J., Eriksson, T., Reeves, P.A., Olmstead, R.G., 2001. Phylogeny and phylogenetic taxonomy of Dipsacales, with special reference to Sinadoxa and Tetradoxa (Adoxaceae). Harvard Pap. Bot. 6, 459479.

Dubatolov, V.V., 1996. A list of the Arctiinae of the territory of the former U.S.S.R (Lepidoptera, Arctiidae). In: Dubatolov, V.V., (Ed.), Contribution to the Knowledge of Palearctiic Arctiinae, vol. 3. Neue Entomologische Nachrichten, Band 37. pp. 39-89.

Emmet, A.M., Watkinson, I.A., Wilson, M.R., 1985. Gracillariidae. In: Heath, J., Emmet, A.M. (Eds.), The Moths and Butterflies of Great Britain and Ireland. Harley Books, Colchester, pp. 244-363.

Environment Canada., 2003. Invasive plants of natural habitats in Canada; Manitoba Provincial Weeds Act. <http://www.cws-scf.ec.gc.ca/ publications/inv/24_e.cfm>.

Farr, D.F., Rossman, A.Y., Palm, M.E., McCray, E.B., 2004. Fungal Databases, Systematic Botany and Mycology Laboratory, ARS, USDA. $<$ http://nt.ars-grin.gov/fungaldatabases/>.

Ferguson, D.C., Harp, C.E., Opler, P.A., Peigler, R.S., Pogue, M., Powell, J.A., Smith, M.J., 1999. Moths of North America. Jamestown, ND: Northern Prairie Wildlife Research Center Home Page. http:// www.npwrc.usgs.gov/resource/distr/lepid/moths/mothsusa.htm (Version 12DEC2003).

Ferguson, I.K., Brizicky, G.K., 1965. Nomenclatural notes on Dipsacus fullonum and Dipsacus sativus. J. Arnold Arbor. Harv. Univ. 46, 362-365.

de Freina, J.J., Witt, T.J., 1987. Die Bombyces und Sphinges der Westpalearktis (Insecta, Lepidoptera). Forscung \& Wissenschaft Verlag $\mathrm{GmbH}$, Munich.

Gibeaux, C., 1988. Sur quatre hôtes du cabaret des oiseaux. Bull. ANVL. $64,69-71$.

Gielis, C., 1996. Pterophoridae. In: Huemer, P., Karsholt, O., Lyneborg, L. (Eds.), Microlepidoptera of Europe 1. Apollo Books, Stenstrup, Denmark, pp. 1-222.

Glass, B., 1991. Vegetation management guidelines: cut-leaved teasel (Dipsacus laciniatus L.) and common teasel (Dipsacus sylvestris Huds.). Nat. Areas J. 11, 213-214.

Gök, A., 2002. Faunistic studies on the species Pachybrachis Chevrolat and Cryptocephalus Geoffroy (Coleoptera, Chrysomelidae, Cryptocephalinae) of the Dedegöl mountains (Isparta). Turk. J. Zool. 28, 3754.

Hall, B., Wood, M., 2001. Suite101.com. Teasel, MY new friend! <http:// www.suite101.com/print_article.cfm/631/75684>.

Harper, M.W., Langmaid, J.R., Emmet, A.M., 2002. Oecophoridae. In: Emmet, A.M., Langmaid, J.R. (Eds.), The Moths and Butterflies of Great Britain and Ireland. Harley Books, Colchester, pp. 43-177.

Harris, P., 1973. The selection of effective agents for the biological control of weeds. Can. Entomol. 105, 1495-1503.

Harris, P., 1991. Classical biocontrol of weeds: Its definition, selection of effective aggents, and administrative-political problems. Can. Entomol. $123,827-849$.

Hering, E.M., 1957. Bestimmungstabellen der Blattminen von Europa. Vol I-II. Uitgeverij Dr. W. Junk-'s-Gravenhage.

Hodges, R.W., 1983. Check List of the Lepidoptera of America North of Mexico. E.W. Classey, London.
Hokkanen, H., Pimentel, D., 1984. New approach for selecting biological control agents. Can. Entomol. 116, 1109-1121.

Huenneke, L.F., Thomson, J.K., 1995. Potential interference between a threatened endemic thistle and an invasive nonnative plant. Conserv. Biol. 9, 416-425.

Iverson, L.R., Ketzner, D., Karnes, J., 1999. Illinois Plant Information Network. Illinois Natural History Survey and USDA Forest Service. $<$ http://www.fs.fed.us/ne/delaware/ilpin/ilpin.html>.

Judd, W.W., 1983. Insects associated with flowering teasel, Dipsacus sylvestris, at Dunnville, Ontario. Proc. Ent. Soc. Ont. 114, 95-98.

Koch, M., 1984. Wir bestimmen Schmitterlinge. Neumann Verlag, LeipzigRadebeul.

Kovacs, T., 1998. Food-plants and locality data of Hungarian longhorn beetles 2. (Coleoptera: Cerambysicdae). Fol. Hist. Nat. Mus. Matr. 22, $247-255$.

Lacourt, J., 1999. Répertoire des Tenthredinidae ouest-paléarctiques (Hymenoptera, Symphyta). Mémoires de la SEF No 3. Société Entomologique de France, Paris.

Liro, J.I., 1942. Neue finnische Eriophyden. Ann Entomol. Fenn. 8, 71-79.

Liston, A.D., 1995. Compendium of European Sawflies. Chalastos Forestry. Daibersdorf 6, Gottfrieding, Germany.

Magis, N., 2001. Apportsà la chorologie des Hyménoptères Symphytes de Belgique et du Grand-Duché de Luxembourg. XXIII. Notes fauniques de Gembloux 43, 39-46.

Magis, N., 2002. Tenthredinidae récoltés en Bulgarie à l'aide de "piège Malaise, sous les auspices de Musée d'Histoire Naturelle de Leiden (van Achtenberg, C., de Vries R., Atanassova, P.V.) (Hymenoptera, Symphyta). Notes fauniques de Gembloux 46, 13-22.

Malecki, R.A., Blossey, B., Hight, S.D., Schroeder, D., Kok, L.T., Coulson, J.R., 1993. Biological control of purple loosestrife. Bioscience 43, 480486.

Mazel, R., 1986. Structure and evolution of the Euphydryas aurinea Rott. populations (Lepidoptera) in the south-west of Europe. Vie Milieu 36, 205-225.

McClay, A.S., 1990. The potential of Larinus planus (Coleoptera:Curculionidae), and accidentally introduced insect in North America, for biologicial control of Cirsium arvense (Compositae). In: Delfosse, E.S. (Ed.), Proceedings of the Seventh International Symposium on Biological Control of Weeds (1988), Istituto Sperimentale per la Patologia Vegetale Ministerio dell'Agricoltura e delle Foreste, Rome, pp. 173-179.

McLaren, D.A., 1992. Observations on the life cycle and establishment of Cochylis atricapitana (Lepidoptera: Cochylidae), a moth used for biological control of Senecio jacobaeae in Australia. Entomophaga 37, 641-648.

Nature's Health Co., 2001. Single herbs. Dipsacus root. <http:// www.nature-s-health.com/products/singleHerbs/ herbInfo.php?itemNum $=$ shb0108\&herbNum $=$ shb0108 $>$.

Novak, I., Severa, F., Luquet, G.C., 1983. Papillons d'Europe. Bordas, Paris.

Nóvoa Pérez, J.M., García-Villanueva, V., 1996. Biology and geographical distribution of Euphydryas desfontainii (Godart, 1819) in the southwest of the Iberian Peninsula (Lepidoptera: Nymphalidae). SHILAP 24, 213-222.

Patch, E.M., 1938. Food-plant catalogue of the aphids of the world including the Phylloxeridae. Maine Agricultural Experiment Station. Bulletin 393. Orono, Maine. pp. 231-232.

Pedigo, L.P., 1989. In: Entomology and Pest Management. Macmillan, New York, p. 646.

Petanovic, R., Stankovic, S., 1999. Catalog of the Eriophyoidea (Acari: Prostigmata) of Serbia and Montenegro. Acta Ent. Serb. (special edition) pp. 1-143.

Petanovic, R., 2001. Three new species of eriophyid mites (Acari: Eriophyoidea) from Serbia with notes on new taxa for the fauna of Yugoslavia. Acta Entomol. Serbica. 4, 127-137.

Pittaway, A., 1993. The Hawkmoths of the Western Palearctic. Harley Books, Colchester.

Quimby Jr, P.C., DeLoach, C.J., Wineriter, S.A., Goolsby, J.A., Sobhian, R., Boyette, C.D., Abbas, H.K., 2003. Biological control of weeds: 
research by the United States Department of Agriculture-Agricultural Research Service: selected case studies. Pest Manag. Sci. 59, 671680.

Razowski, J., 1970. Cochylidae. In: Amstel, H.G., Gregor, F., Reisser, H., (Eds.), Microlepidoptera Palaearctica, 3, Vienna, pp. 1-528.

Rejzek, M., Sama, G., Alzier, G., Sáldo, J., 2003. Host plants of longhorn beetles (Coleoptera: Cerambycidae) from the Balkan Peninsula, Asia Minor, and Iran (part II). Biocosme. Mesogeen. 19, 161-189.

Roberts, H.A., 1986. Seed persistence in soil and seasonal emergence in plant species from different habitats. J. Appl. Ecol. 23, 639-656.

Rosenthal, S.S., Clement, S.L., Hostettler, N., Mimmocchi, T., 1988. Biology of Tyta luctuosa and its potential value as a biological control agent for the weed Convolvulus arvensis. Entomophaga 33, 185-192.

Ryder, M.L., 1998. Raising teasels to raise cloth. Textiles 27, 9-11.

Sforza, R., 2004. Candidates for biological control of teasel, Dipsacus spp. In: Cullen, J.M., Briese, D.T., Kriticos, D.J., Lonsdale, W.M., Morin, L., Scott, J.K. (Eds.), Proceedings of the XI International Symposium on Biological Control of Weeds. CSIRO Entomology, Canberra, pp. 155-161.

Singhurst, J.R., Holmes, W.C., 2001. Dipsacus fullonum (Dipsacaceae) and Verbesina walteri (Compositae): New to Texas. Sida: Contributions to Botany 19, 723-725.

Skolnik, J., 1999. Ask a scientist biology archive. U.S. Dept. of Energy, Argonne National Laboratory, Division of Educational Programs, NEWTON-BBS. < < <ttp://www.newton.dep.anl.gov/askasci/bio99/ bio99464.htm>.

Solecki, M.K., 1989. The viability of cut-leaved teasel (Dipsacus laciniatus L.) seed harvested from flowering stems: management implications. Nat. Areas J. 9, 102-106.

Steinhausen, W.R., 1996. Biological remarks on rearing and collecting of middle European leaf beetle larvae. In: Jolivet, P.H.A., Cox, M.L. (Eds.), Chrysomelidae Biology, vol. 3: General Studies. SPB Academic Publishing, Amsterdam, pp. 93-105.

Stoner, W.N., 1951. An aphid-transmitted virus disease of fuller's teasel and pincushion flower. Phytopath 41, 191-194.

Tabor, R., 2003. Pilgrims taking herbs to America. The Herb Society. $<$ http://dspace.dial.pipex.com/herbsociety/articles.htm>.

Taeger, A., Altenhofer, E., Blank, S.M., Jansen, E., Kraus, M., PschornWalcher, H., Riztau, C., 1998. Kommentare zur Biologie, Verbreitung und Gefährdung der Pflanzenwespen Deutchlands (Hymenoptera, Symphyta). In: Taeger, A., Blank, S. (Eds.), Pflanzenwespen Deutch- lands. Deutches Entomologishces Institut, Verlag Goecke \& Evers, Keltern, pp. 49-135.

Teeguarden, R., 2004. Dipsacus. Dragon herbs. <http://www.dragonherbs.com/herbs/herbs.asp?herb_id $=14706>$.

Thorne, G., 1945. Ditylenchus destructor, n. sp., the potato rot nematode, and Ditylenchus dipsaci (Kühn, 1857) Filipjev, 1936, the teasel nematode (Nematoda: Tylenchidae). Proc. Helminth. Soc. Washington 12, 27-34.

Topham, P.N., 1968. The fuller's teasel. Proc. Bot. Soc. Br. Isl. 7, 377-380.

Trematerra, P., Baldizzone, G., 2004. Records of Lepidoptera Tortricidae from Krk Island (Croatia). Entomol. Croat. 8, 25-44.

USDA, NRCS, 2004. The PLANTS Database, Version $3.5(<\mathrm{http} / /$ plants.usda.gov $>$ ). National Plants Data Center, Baton Rouge, LA 70874-4490 USA.

USDI-NPS, 2003. U.S. Dept. of Interior, National Park Service; Alien Plant Invaders of Natural Areas. (<http://www.nps.gov/plants/alien/ list/d.htm>).

Vassilev, I.B., 1978. Fauna Bulgarica. Vol 8: Hymenoptera, Symphyta. Aedibus Academiae Scientiarum Bulgaricae. Sofia, Bulgaria, pp. 22-23.

Verlaque, R., 1985. Etude biosystematique et phylogenetique des Dipsacaceae. III. Tribus des Knautieae et des Dipsaceae. Rev. Cytol. Biol. Veget-Bot. 8, 171-243.

Wahlberg, N., 2001. The phylogenetics and biochemistry of host-plant specialization in melitaeine butterflies (Lepidoptera: Nymphalidae). Evolution 55, 522-537.

Wapshere, A.J., 1974. A strategy for evaluating the safety of organisms for biological weed control. Ann. Appl. Biol. 77, 201-211.

Warchalowski, A., 2003. Chrysomelidae. The Leaf-Beetles of Europe and the Mediterranean Area. Natura optima dux, Warsaw.

Werner, P.A., 1975a. The biology of Canadian weeds: 12. Dipsacus sylvestris Huds. Can. J. Plant. Sci. 55, 783-794.

Werner, P.A., 1975b. Predictions of fate from rosette size in teasel (Dipsacus fullonum L.). Ecologica. 20, 197-201.

Werner, P.A., 1975c. The effects of plant litter on germination in teasel, Dipsacus sylvestris Huds. Am. Midl. Nat. 94, 470-476.

WSSA, 2005. Weed Science Society of America. Common and Latin name index. <http://www.wssa.net/CLNAMES/namesearch.asp>.

Zhang, W.H., Chen, Z.D., Li, J.H., Chen, H.B., Tang, Y.C., 2003. Phylogeny of the Dipsacales s.l. based on chloroplast trnL-F and ndhF sequences. Mol. Phylogenet. Evol. 26, 176-189. 